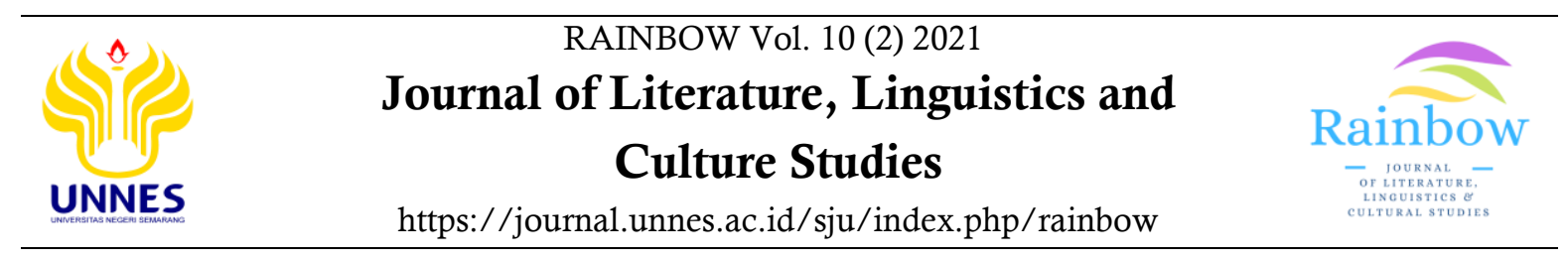

\title{
Skin whitening as a menace to African identity through Tony Morrison's The Bluest Eyes: An Afrocentric examination
}

\author{
Malesela Edward Montle
}

Department of Languages: English Studies, University of Limpopo, South Africa

\begin{tabular}{ll}
\hline Article Info & Abstract \\
\hline $\begin{array}{l}\text { Article History: } \\
\text { Received }\end{array}$ & $\begin{array}{l}\text { The African democratic forces aimed to resuscitate and re-essentialize African identities } \\
\text { that the colonial administration had endangered earlier. These autonomous corps } \\
\text { Approved }\end{array}$ \\
$\begin{array}{l}\text { 06 October 2021 } \\
\text { dispensed mechanisms to champion Africanism. This has inculcated an urge into Africans } \\
\text { to be proud of their heritage. Notwithstanding these efforts, the study diagnoses skin } \\
\text { 30 October 2021 }\end{array}$ & $\begin{array}{l}\text { whitening as a stubborn nemesis that menaces Africanism today. Many Africans, especially } \\
\text { black women appear to be gravitated to skin whitening. Most of the skin whiteners are } \\
\text { Keywords: }\end{array}$ \\
$\begin{array}{l}\text { pfrican identity, } \\
\text { polourism, }\end{array}$ & $\begin{array}{l}\text { beauty, which are driven by Eurocentric influence. The paper has employed a qualitative } \\
\text { Democracy, }\end{array}$ \\
$\begin{array}{l}\text { Eurocentricity, } \\
\text { Identity-crisis, Skin } \\
\text { imhitening }\end{array}$ & $\begin{array}{l}\text { Afrocentricity as it aids Africans to embrace their aboriginal identities and antagonize } \\
\text { Eurocentric menaces such as skin whitening. It has also used Morrison's The Bluest Eyes as }\end{array}$ \\
& $\begin{array}{l}\text { a lens to crystalize the impacts of skin whitening on Africanism. The paper has discovered } \\
\text { that skin whitening perpetuates Eurocentric ideologies, and most women prefer it because } \\
\text { of the assumed glory that comes with the whiteness such as privilege and attractiveness. }\end{array}$
\end{tabular}

(C) Copyright 2021

How to cite (in APA Style):

Author 1, Author 2, \& Author 3. (20XX). Title of the manuscript. Rainbow: Journal of Literature, Linguistics and Culture Studies, $\mathrm{X}(\mathrm{X}), 48-56$. https://doi.org/XXXX

\section{INTRODUCTION}

The European forces conquered Africa between 1800 and 1900, and enforced Western cultures, attitudes, and perceptions upon African natives. This menaced the aboriginal African identities that Africans solely relied on prior to contact with the West. Thus, the African democratic corps, upon taking reigns, set to rehabilitate African identities and eradicate the colonial undertones that formerly distinguished the African continent. The colonial tinges included the exaltation of Eurocentricity at the expense of Afrocentricity. For instance, the colonialists during their rule stigmatised the depiction of Afrocentric beauty and championed Eurocentric epitomes in the continent. Gradually, the Eurocentric ideals of beauty, often epitomised by white skin tones, long hair and thinness became the most predominant and acceptable narrative of beauty in African societies even after the dethronement of the colonial administration. Tate (2007, p. 301) notes that it is the "white European images of beauty, described as delicate, fine, with light features, seen as the ideal discourses of beauty in western society and Black women seen as strong and exuding animal sensuality." Today, many women whose physical characteristics do not conform to the Eurocentric standards of beauty often engage in practices such as skin whitening, which the paper

$\begin{array}{lr}{ }^{凶} \text { Corresponding author: } & \text { p-ISSN: 2252-6323 } \\ \text { E-mail: } \underline{\text { edward.montle@ul.ac.za }} & \text { e-ISSN: 2721-4540 }\end{array}$


specifically seeks to examine as a menace to African identity.

Skin whitening involves the use of chemical products; creams and lotions to alter one's dark skin colour to be light. Correspondingly, Couteau and Coiffard (2016, p. 17) describe skin-whitening as the "using of natural or synthetic substances to lighten the skin tone or provide an even complexion by reducing the melanin concentration in the skin." The descriptions above seem to confirm that skin-whitening compromises the black identity-an essential element that underpins Africanism. Thus, scholars such as Mushure (2010) and Montle (2020) perceive the practice of skin-whitening as an indication of self-hatred, rejection of African identity and succession of the colonialists' favour of whiteness over blackness. On IOL news (09 June 2019), Latashia Naidoo writes that "after generations of colonial rule and apartheid subjugation, academics claim that the residual effects of these past traumas have now manifested themselves in the face of colourism: an identity bias skewed towards the belief that white is right." Furthermore, black women are increasingly practising skin-whitening and most of their reasons revolve around the credence that 'white is right'. For instance, on the IOL news (09 June 2019), several African women admitted to using skin-whiteners and when asked why, one said, "there was something about a woman who looks brighter", and another responded, "Ima (sic) bleach until Jesus comes." This noted, the paper hinges on the question:

Does skin-whitening threaten African identity?

\section{LITERATURE REVIEW}

The pre-colonial African societies often depicted short hair(styles), Afro-textured hair, black appearances and curvaceousness as canons of African beauty. These qualities are brilliantly typified by Saartjie Baartman whom the colonialists stereotyped and exploited due to her outstanding subscription to the African ideals of beauty. Baartman was an African woman who endured tremendous hardships meted out by the colonialists due to her astonishing physical appearance. Her case lingers as one of the lens systems that crystalise the foundations of racial tension and discrimination against African identities. Spies (2014, p. 48) asserts that "two centuries after her death, Saartjie Baartman, a South African Khoikhoi woman, has come to be regarded as a female icon and a symbol of the struggle for human rights in debates on race, gender and otherness." It is the colonialists that imbibed African identities and de-valued the African perception of beauty. To a greater extent, African identities such as the black skin colour became associates of inferiority, poverty, and failure as the colonial administration empowered white elites at the expense of the black masses of Africa. For instance, the colonialists sold Baartman and other African natives amongst themselves to subject them to domestic work, hard labour, and other sub-standard occupations. Hall (1990, p. 225) affirms that "the ways in which black people, black experiences, were positioned and subjected in the dominant regimes of representation were the effects of a critical exercise of cultural power and normalisation." This noted, success was normalised as a contact of the white identity. Which is why, then, most African natives that yearned for success proselytised into Eurocentric thinking and adopted the colonialists' identities. Moreover, the colonialists conquered several parts of Africa with the aid of other African natives who joined forces with the colonial elites in an effort to attain success. These Africans also adopted the religion of the colonialists. According to Sahistory.org (2015), "the Europeans were able to colonise African countries rapidly because there were rivalries between African leaders. During these rivalries, European leaders would take advantage of the situation and persuaded some leaders to be on their side to fight against other leaders." Furthermore, this ordeal manifests through skin whitening today. Like the African natives who adopted Eurocentric identities in an effort to secure success during the colonial era, some black women in the democratic dispensation conform to the Eurocentric epitomes of beauty to also attain success, hence they brighten their skins 
using skin whitening products. Pumza $(2013,1)$ asserts that "women with a lighter skin are thought to be more beautiful and likely to find success than women with darker skin tones." This phenomenon is progressively exercised in the present-day in an effort to achieve success because whiteness appears to be associated with:

\section{Privilege}

Racial identity in the African context has played a major role in the distribution of opportunities during the colonial administration. This could be exemplified by the white privilege that distinguished South Africa in the course of apartheid. The apartheid system perpetuated the colonial policies of segregation and engineered discrimination against non-whites in the country. This government reserved prestigious opportunities for the white minority in the African state. For instance, it has passed laws such as The Extension of University Act, Act 45 of 1959 which declared that it is illegal for non-whites to enrol at an open university without authorisation from the Minister of Internal Affairs (Padraig, 2010). Another law is The Bantu Education Act, Act 47 of 1953 which reserved low-quality education for non-whites. Lastly, The Reservation of the Separate Amenities Act, Act 49 of 1953 that enforced racial separation regarding the use of public facilities. The advanced amenities were reserved for whites and unfavourable ones for nonwhites. Nevertheless, colonial systems such as apartheid were eventually subdued by democratic forces. Despite the political transition from autocracy to democracy, Sall (2018, p. 14) states that "racial division and white privilege is a reality in South Africa...colour-blind ideologies such as the rainbow nation defend white privileges and reinforce the blindness towards awareness of white privilege." This is undergirded by motivation for skin whitening which features white privilege in the centre. Several skin whiteners have admitted to using the products for privilege during the colonial and present times. Jacobs et al. (2016, p. 552) point out that in the colonial times "individuals with lighter skin received greater privilege than those of darker skin tones." This colonial custom still domineers in the present day Africa and heads the beauty industry. Backhaus and Okunmwendia (2020, p. 1) in their study on skin bleaching in Ghana note that "when you are light-skinned, you earn more. Some pregnant women take tablets in the hopes that it will lead their child to be born with fair skin. Some apply bleaching lotion...to their babies, in the hopes that it will improve their child's chances."

\section{Attractiveness}

Physical beauty is an essential aspect of womanhood. It is one of the women's significant cornerstones of self-esteem. Due to the Eurocentric connotations that suggest that beauty depends on the degree of skin whiteness, Dlova et al. (2014) find that over a third of 579 women who participated in their study noted that a brighter skin improved their confidence. Therefore, many women resorted to skin whitening and considered a dark skin stone as "embarrassing and humiliating" (Gwaravanda 2011, p. 201). These remarks, inter alia, invalidate African identity and the prospect of future generations of Africa celebrating who they are, where they come from and how they look. Hence, Durosaro et al. (2012, p. 40) assert that "black people may be obliged to bleach their skin in order to rid themselves of the stigma attached to their skin tone, especially when in pursuit of opportunities." This would directly affect the central characteristics and constructiveness of Africanism. Correspondingly, Manganyi (1973, p. 3) avers that "constructing the black identity is best done by those coming from Africa because it is on the African continent, where the great and intricate drama of being-black-in-theworld is taking place." This noted, the erosion of the black identity would menace the authenticity of Africanism. Furthermore, the practice of skin whitening is reinforced by the belief that men find women with brighter skin tones more attractive than the ones with dark skin tones. A female participant in Gwaravanda's (2011, p. 201) study utters, "if I am to keep my boyfriend from being snatched away by other ladies, skin bleaching is the only solution" whereas another woman in Lewis et al.'s study (2011, p. 33-34) affirms, "I use skin 
bleaching to attract my friends" and the other in the same study claims, "men love women who have soft skin ... people apply creams and lotions to make their skin soft." Moreover, confirmatory evidence for the above postulations could be sought from the findings of Makobela (2019, p. 76) where a male participant in the study said, "whenever, I see a light-skinned woman I think that she is pretty without looking at other features you know, but that's what has been, ah, customised in my mind, that's what has been drilled, you know, according to the society, according to what I see in media." Another male participant in the study noted, "uhm, no, not actually, like for me as I said, women can be beautiful, like any women can be beautiful. I've seen dark girls who are beautiful, there are light skin girls who are beautiful, but yeah, eish, the fact is that light skin women are like more beautiful though" (Makobela 2019, 76). Based on the information above, men seem to prefer women with lighter skin tones and this enkindles the practice of Skin whitening.

\section{METHODS}

This study utilises a qualitative method to comprehend and examine the phenomenon of skin whitening from a literary perspective. It has purposively sampled Tony Morrison's The Bluest Eyes amongst other African narrations that mirror African issues such as identity-crisis. Morrison's work stands out as a literary reflection that portrays the impacts of skin whitening on African identity. For this reason, the researcher chose to use Morrison's narration as a primary reference point for the study. The data collected from the novel is supplemented by information from journal articles, critical books, and newsletters. Moreover, the study adopts a qualitative content analysis technique to critically assert, discuss and analyse the findings from Morrison's The Bluest Eyes.

\section{RESULTS AND DISCUSSION}

The study has chosen Tony Morrison's The Bluest Eye (1970) as a case in point to succeed in its Afrocentric examination of skin whitening as a menace to Africanism. A qualitative content analysis technique has been adopted to critically present, analyse and discuss the findings from the novel. The findings from the novel are presented in themes:

\section{Colourism}

Morrison's The Bluest Eyes is a post-colonial narration that mirrors the issue of identity-crisis. It points out desperation and obsession with beauty as maladies that threaten the African identity. The novel revolves around the life of an 11-year-old black girl, Pecola, who experiences criticism, rejection, and racist treatment from her community due to her 'too dark skin tone' as understood by her community. Pecola confronted annotations about her being ugly because she is black. For instance, a girl with a lighter skin tone, Maureen berates Pecola and claims that she is prettier than her, "I am cute! And you ugly! Black and ugly e mos. I am cute!" (Morrison 1970, p. 35). This is a depiction of colourism, which is discrimination of dark-skinned people usually by people of the same race. Morrison portrays Maureen as a subscriber of Eurocentric standards and her to reach to some of the levels of Eurocentricity influenced her demeaning behaviour towards her African sisters:

This disrupter of seasons was a new girl in school named Maureen Peal. A high yellow dream child with long brown hair braided into two lynch ropes that hung down her back. She was rich, 54 at least by our standards, as rich as the richest white girls, swaddled in comfort and care. The quality of her clothes threatened to derange Frieda and me (Morrison 1970, p. 3).

The pessimism against Pecola's black identity instilled self-hatred in her as she began to believe that she is inferior and ugly because of her dark skin stone. Whiteness succeeds in being associated with purity, godliness, innocence, and beauty in the novel. For instance, Soaphead Church grew up in a family that preferred to marry partners with lighter skin tones in an effort to whiten the family's characteristics and culture. Moreover, Pecola is distinguished for her 'too dark skin' and is typically known as the 'ugly black girl' in her community,

They lived there because they were poor and 
black, and they stayed there because they believed they were ugly. Although their poverty was traditional and stultifying, it was not unique. But their ugliness was unique. No one could have convinced them that they were not relentlessly and aggressively ugly (Morrison 1970, p. 1).

In an effort to remedy her problem, Pecola embarked on a task to adopt a white identity as the black identity escalated to being a curse for her and her family. This is because "adults, older girls, shops, magazines, newspapers, windows signs- all the world had agreed that a blue-eyed, yellow haired, pink skinned doll was what every girl child treasured" (Morrison 1970, 39). Pecola's father, Cholly was dehumanised by white men as a result of being black and this ordeal infuriated and propelled him to loathe blackness, hence he raped his daughter Pecola who was mostly known as the epitome of black identity in the community. Furthermore, to alter her physical appearance, Pecola considered having the bluest eyes ever. Hence, the title of the novel is The Bluest Eyes. According to Moyer $(2019, \mathrm{i})$, "blue eyes are most common in Europe, especially Scandinavia. People with blue eyes have the same genetic mutation that causes eyes to produce less melanin. The mutation first appeared in a person living in Europe about 10,000 years ago. That individual is a common ancestor of all blue-eyed people today." Essentially, blue eyes in the novel represent whiteness and Pecola desires to have them in order escape from the confines of ugliness attached to her African identity.

Here was an ugly little girl asking for beauty...A little black girl who wanted to rise up out of the pit of her blackness and see the world with blue eyes. His outrage grew and felt like power. For the first time he honestly wished he could work miracles (Morrison 1970, p. 21).

\section{Identity-crisis}

Pecola and other black characters such as Geraldine and Maureen are stigmatised for their African identities and perceive the acquisition of Whiteness as an escape from the societal backlash. Midzi $(2019$, 53) asserts that "all the characters who have internalised popular and cultural concepts of goodness, beauty and innocence tend to have some kind of covert or overt with whiteness." This perception is reinforced by the inspiring sentiments about Eurocentric standards of beauty depicted in media platforms such as magazines, movies and newspapers. Gooden (2011, p. 87) avers that "the media depicts white ideals of beauty as the beauty commodity that black women must possess to be successful." In the novel, Pauline was never able, after her education in the movies, to look at a face and not assign it some category in the scale of absolute beauty, and the scale was absorbed in full from the silver screen" (Morrison 1970, p. 122). She has learnt from the movies that to attain beauty and be attractive, one has to conform to Eurocentric ideals:

Along with the idea of romantic love, she was introduced to another physical beauty. Probably the most destructive ideas in the history of human thought. Both originated in envy, thrived in insecurity and ended in delusion. (Morrison 1970, p. 98).

Consequently, Midzi (2019, p. 20) notes that Morrison's The Bluest Eyes "acknowledges that if whiteness is used as a standard of beauty or anything else, then the value of blackness is diminished." In the novel, Geraldine's family cherished whiteness over blackness and made extreme efforts to dissipate the black identity from their lives. The attempts to fit into the white society include Geraldine discouraging her son from befriending black kids:

His mother did not like him to play with niggers [a derogatory term to refer to black or dark-skinned people, mostly African Americans]. She had explained to him the difference between coloured people and niggers, they were easily identifiable. Coloured people were neat and quiet; niggers were dirty and loud (Morrison 1970, p. 14).

In line with the above, Geraldine imposed skin whitening techniques upon her son throughout his childhood in an effort to prepare him for the successes that come with a light skin. To attain lighter skin tones, Geraldine "bathed her son with orange-coloured Lifebuoy soap, dusted twith Cashmere talc, cleaned teeth with salt on a piece of rag, soften their skin with Jergens Lotion. They smell like wood, newspapers, and vanilla" (Morrison 1970, p. 83). According to Glenn (2008), a lighter skin tone possesses a social capital 
that is utilised to achieve socio-economic and political success. Thus, Geraldine is obsessed with changing the skin tone of his son to be white,

In the winter his mother put Jergens Lotion on his face to keep the skin from becoming ashen. Even though he was light-skinned, it was possible to ash. The line between colour and nigger was not always clear, subtle and tell-tale signs threatened to erode it, and the watch had to be constant (Morrison 1970, p. 87).

As has been noted, Pecola, Pauline, Geraldine and Maureen glorify whiteness and sacrificed their African identities in order to fit into the white society. Pecola ultimately believes that she should have blues eyes that she read about in Dick and Jane where the characters with blue eyes were privileged, valued, and admired in the society,

Here is the house. It is green and white. It has a red door. It is very pretty. Here is the family. Mother, Father, Dick and Jane live in the greenand-white house. They are very happy...Mother is very nice... See Father. $\mathrm{He}$ is big and strong... See the dog. Bow wow goes the dog (Morrison 1970, p. 3).

\section{Skin whitening}

Equally important, Geraldine and Maureen on the other hand, resorted to skin whitening in order to qualify into the white society and their attainment of light skin stones engendered Negrophobia. Brooks (2012, p. 113) notes that "Negrophobia is characterised by a fear, hatred or extreme aversion to black people and black culture worldwide caused amongst other factors by racism and traumatic events. This phobia includes the attribution of negative characteristics to black, the fear and strong dislike of black men and the objection of black women." Geraldine forbade his son from being friends with "niggers". Both Geraldine and Maureen, although Africans with light complexions, developed a dislike for 'too dark-skinned' Africans such as Pecola. Maureen regards Pecola as black and ugly and herself as light and cute (Morrison 1970, p. 35). Eurocentric perceptions of beauty domineered the lives of the characters in the novel and those that did not possess white characteristics endured discrimination. Thus, Pauline decided to break away from the African identity in order to be at peace and valued, "She, like a Victorian parody, learned from her husband all that was worth learning- to separate herself in body, mind and in spirit from all that suggested Africa" (Morrison 1970, p. 7).

Morrison points out Geraldine, Maureen, Pauline and Pecola's obsession with the white identity as self-hatred and rejection of the African identity through the character of Claudia. This character holds a different perception regarding beauty. She also endured discrimination owing to her dark skin tone, unlike the other black characters, Claudia chose to be proud of her black identity and cherish it. This could be demonstrated by her rejection of the white baby doll which other characters such as Pecola embraced because of its whiteness. Hence, she dissembled the doll "to see what it was made of, and also to discover the dearness, and to find the beauty and examine it to see what it was that the world said was lovable" (Morrison 1970, p. 39). Moreover, Claudia realises that the minds of other characters such as Maureen are still entrapped within the margins of colonial influence that perpetrated discrimination against African identities. Ngũgi Wa Thiong'o (1981) in Decolonising the Mind, refers to colonialism as a "cultural bomb that dismantles people's belief in their names, languages, environment, heritage of struggle, unity, as well as their capacities, and ultimately in themselves." In the novel, Claudia understands that Maureen who had disregarded Pecola for being 'too dark-skinned' "was not the Enemy and not worthy of such intense hatred. The Thing to fear was not the Thing that made her beautiful" (Morrison 1970, p. 74). This noted, Claudia admired Pecola and encouraged her and other black characters to proud be of who they are, "more strongly than my fondness for Pecola, I felt a need for someone to want the black baby to just live just to counteract the universal love of white baby dolls, Shirley Temples and Maureen Peals" (Morrison 1970, p. 190).

\section{CONCLUSION}

This paper sought to unveil the menace that skin whitening poses to the African identity. The 
findings from Morrison's The Bluest Eyes have confirmed that black individuals resort to skin whitening to attain success and attraction. This was demonstrated through Geraldine's efforts to whiten the skin of her son from childhood so that he would be privileged in his adulthood due to his complexion. This, among other things, threatens the African identity. The discriminated Africans in the novel decided to break away from their African identity and distance themselves from everything that epitomises Africanism in an effort to adopt the white identity that comes with adoration and opportunities. Makobela $(2019,112)$ states that "because of colonisation most people value light skin over dark skin because they are still brainwashed." Furthermore, the association of whiteness with beauty and privilege, and blackness with ugliness and inferiority is a mindset perpetuated by colonial forces. Therefore, to revalidate and essentialise African identities, the study recommends that initiatives be undertaken to address and dissolve the enduring legacies of colonialism.

\section{REFERENCES}

Backhaus, A \& Okunmwendia, E. (2020). When You Are Light-Skinned, You Earn More. https,//www.spiegel.de/international/world/s kin-bleaching-in-ghana. Accessed, 2021/04/26.

Brooks, A. (2012). Black Negrophobia and Black SelfEmpowerment, Afro-Descendant Responses to Societal Racism in São Paulo, Brazil. UW-L Journal of Undergraduate Research, 25(2), 1-11.

Couteau, C \& Coiffard, L. (2016). Overview of Skin Whitening Agents, Drugs and Cosmetic Products. Cosmetics, 3(27), 1-17.

Dlova, N.C., Hamed, S.H., Tsoka-Gwegweni, J., \& Grobler, A. (2015). Skin lightening practices, An epidemiological study of South African women of African and Indian ancestries. British Journal of Epidemiology, 173(52), 2-29.

Durosaro, A.I., Ajiboye, S.K., \& Oniye, A.O. (2012). Perceptions of skin bleaching among female secondary school students in Ibadan Metropolis Nigeria. Journal of Education and Practice, 3(7), 40 46.

Glenn, E.N. (2008). Yearning for lightness. Gender and Society, 22(3), 281-302.
Gooden, A. (2011). Visual representations of feminine beauty in the black press, 1915-1950. Journal of Pan African Studies, 4(4), 81-97.

Gwaravanda, E.T. (2011). Shona proverbial implications on skin bleaching, Some philosophical insights. Journal of Pan African Studies, 4(1), 195-218.

Hall, S. (1990). Cultural identity and diaspora. http,//sites.middlebury.edu/nydiasporaworksh op. Accessed, 2021/04/26.

Jacobs, M., Levine, S., Abney, K. \& Davids, L. (2016). Fifty shades of African lightness, A biopsychosocial review of the global phenomenon of skin lightening practices. Journal of Public Health in Africa, 7(2), 67-70.

Lewis, K.M., Robkin, N., Gaska, K., \& Njoki, L.C. (2011). Investigating motivations of women"s skin bleaching in Tanzania. Psychology of Women Quarterly, 35(1), 29-39.

Makobela, T. (2019). Perceptions of Black Men in Katlehong about Female "Yellow Bones", A Case Study. Masters dissertation. University of Johannesburg, Johannesburg.

Manganyi, N.C. (1973). Being-Black-in-the-world. SPROCAS, Johannesburg.

Midz, P. I. (2019). A comparative analysis of identity and belonging in Kopano Matlwa's coconut and Tony Morrison's "The Bluest Eyes". MA dissertation. University of Namibia, Namibia.

Montle, M. E. (2020). Debunking Eurocentric ideals of beauty and stereotypes against African natural hair(styles), An Afrocentric perspective. Journal of African Foreign Affairs, 7(1), 111-127.

Morrison, T. (1970). The Bluest Eye. London, UK, Pan Books.

Moyer, N. (2019). Eye Spy, Worldwide Eye Colour Percentages.

https,//www.healthline.com/health/eyehealth/eye-color-percentages. Accessed, 2021/04/26.

Mushure, M. (2010). Why do black African women use hair extensions? Exploring reasons for the popularity of hair extensions among black African women. Masters dissertation. Cape Town, University of Cape Town.

Ngugi wa Thiong'o. (1981). Decolonizing the mind, The politics of language in African literature. London, James Currey.

Padraig, O. (2010). 1959. Extension of University Education Act No 45. Nelson Mandela Center of Memory and Dialogue. Accessed, 2021/04/26. 
Pumza, F. (2013). Africa, Where black is not really beautiful. https, //www.bbc.com/news/world-africa20444798. Accessed, 2021/04/26.

Sall, T. L. (2018). The rainbow myth, Dreaming of a postracial South African Society. Ocassional paper 73. Institute for Global Dialogue (IGD).

South African History Online. (2015). https,//www.sahistory.org.za. Accessed, 2021/04/26.

Spies, B.M. (2004). Alban Berge's Wozzeck, Revisiting a Historically Sedimented Metaphor. South African Journal of Musicology, 22(1),47-61.

Tate, S. (2007). Black beauty, Shade, hair and anti-racist aesthetics. Ethnic and Racial Studies, 30(2), 300319. 